\title{
From precipitation to groundwater baseflow in a native prairie ecosystem: a regional study of the Konza LTER in the Flint Hills of Kansas, USA
}

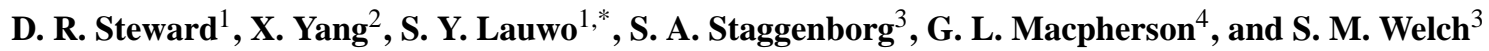 \\ ${ }^{1}$ Kansas State University, Department of Civil Engineering, 2118 Fiedler Hall, Manhattan, Kansas, 66506-5000, USA \\ ${ }^{2}$ Fudan University, Department of Environmental Science and Engineering, Shanghai, China \\ ${ }^{3}$ Kansas State University, Department of Agronomy, 2004 Throckmorton Plant Sciences Center, Manhattan, \\ Kansas, 66506-5506, USA \\ ${ }^{4}$ University of Kansas, Department of Geology, 1475 Jayhawk Blvd, Room 120, Lawrence, Kansas, 66045-7594, USA
}

Received: 17 March 2011 - Published in Hydrol. Earth Syst. Sci. Discuss.: 28 April 2011

Revised: 5 October 2011 - Accepted: 7 October 2011 - Published: 20 October 2011

\begin{abstract}
Methods are developed to study hydrologic interactions across the surficial/groundwater interface in a native prairie ecosystem. Surficial ecohydrologic processes are simulated with the USDA's EPIC model using daily climate data from the Kansas Weather Data Library, vegetation and soil data from the USDA, and current land-use management practices. Results show that mean annual precipitation (from 1985-2005) is partitioned into $13 \%$ runoff regionally and $14 \%$ locally over the Konza LTER, lateral flow through soil is $1 \%$ regionally and $2 \%$ locally, groundwater recharge is $11 \%$ regionally and $9 \%$ locally, and evapotranspiration accounts for the remaining $75 \%$. The spatial distribution of recharge was used in a regional Modflow groundwater model that was calibrated to existing groundwater observations and field measurements gathered for this study, giving a hydraulic conductivity in the Flint Hills region of $1-2 \mathrm{mday}^{-1}$ with a local zone (identified here) of $0.05-0.1 \mathrm{~m} \mathrm{day}^{-1}$. The resistance was set to fixed representative values during model calibration of hydraulic conductivity, and simple log-log relations correlate the enhanced recharge beneath ephemeral upland streams and baseflow in perennial lowland streams to the unknown resistance of the streambeds. Enhanced recharge due to stream transmission loss (the difference between terrestrial runoff and streamflow) represents a small fraction of streamflow in the ephemeral upland and the resistance of this streambed is 100000 day. Long-term baseflow in the local Kings Creek watershed (2\% of the groundwater
\end{abstract}

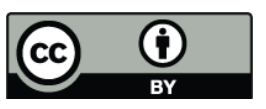

Correspondence to: D. R. Steward (steward@ksu.edu) recharge over the watershed) is met when the resistance of the lowland streambed is 1000 day. The coupled framework developed here to study surficial ecohydrological processes using EPIC and groundwater hydrogeological processes using Modflow provides a baseline hydrologic assessment and a computational platform for future investigations to examine the impacts of climate change, vegetative cover, soils, and management practices on hydrologic forcings.

\section{Introduction}

Groundwater plays an important role in ecohydrological processes and interactions. Within terrestrial ecosystems, recharge to groundwater stores occurs from the portion of precipitation that does not either evapotranspire back to the atmosphere or runoff the land to surface water. Important hydrological interactions also occur across the surficial/groundwater interface in stream channels. Transmission losses in ephemeral streams provide enhanced recharge to groundwater beneath the hyporheic zone. Groundwater provides baseflow discharge to perennial streams, which is important to aquatic ecosystems and riparian habitat (Hayashi and Rosenberry, 2002). This study addresses the need for theoretical frameworks to capture the complex interactions across hydrological processes and plant ecosystems (Porporato and Rodrigues-Iturbe, 2002).

The study region encompasses the Konza Prairie LongTerm Ecological Research (LTER) station in the Flint Hills of Kansas. Konza is a founding member in the International LTER Network and provides the core prairie grassland

Published by Copernicus Publications on behalf of the European Geosciences Union. 
site in a proposed National Ecological Observatory Network (NEON). Konza is also NASA's First ISLSCP (International Satellite Land Surface Climatology Project) Field Experiment (FIFE) to study land-atmosphere interactions. Positioned near the centroid of the continental USA, the study region may provide a bellweather for environmental change (Hayden, 1998, p.34) since changes in patterns of water availability from predicted climate change are likely to greatly impact tallgrass prairie ecosystems (Collins et al., 1998, p.311).

A number of previous investigations have studied hydrologic processes at Konza. The data from remote sensing in FIFE and more recent studies have been used with field level weather measurements to study evapotranspiration at Konza (Famiglietti et al., 1992; Famiglietti and Wood, 1994, 1995; Gutowski Jr. et al., 2002; Brunsell et al., 2008). Famiglietti et al. (1992) recommended for future models to incorporate soil water storage and groundwater flow, and Gutowski Jr. et al. (2002) suggested that future models should take into account overland runoff. Dodds et al. (1996) studied the movement of surface runoff through stream channels and observed that one third of the hydrologic export flows directly through the stream while transmission losses account for the remaining which flows through shallow groundwater and the hyporheic zone and much of this eventually reimmerges from bank storage to groundwater. Macpherson (1996) showed that local groundwater mounds on the order of $1 \mathrm{~m}$ or less form in stream banks in response to precipitation events during periods of low evapotranspiration. Paniconi and Wood (1993) modeled unsaturated flow in the upper $1 \mathrm{~m}$ of the local Kings Creek watershed and Macpherson and Sophocleous (2004) concluded that there is little change in soil moisture below one meter depth with no apparent pulsed or wavelike water movement through the vadose zone and that flow through macropores is not significant at this site. York et al. (2002) developed a local groundwater model at the nearby Mill Creek and adopted this steady-state assumption.

This study provides a hydrologic assessment of the Konza LTER site that incorporates evapotranspiration, surficial runoff, recharge to groundwater through the vadose zone, and the interactions of groundwater and surface water. Surficial models are evaluated over $21 \mathrm{yr}$ of weather data to quantify fluxes across the spatial characteristics of the landscape. The subsurface hydrology of Konza is studied within a regional model that incorporates the forcings and interactions of its setting. Estimates of mean annual recharge occurring across the region will be developed, as well as understanding of how the streams are influencing the water budget. The motivation of this study is to develop ecoforecasting tools capable of studying the impact of change with methods applicable to other biomes and geologic regions of the world.

\section{Methods}

The landscape of the Konza region is illustrated in the photographs in Fig. 1. Important variables and interactions used to describe the hydrology of this system are found in the conceptual overview in Fig. 1c. This section provides an overview of the study region and then presents the computational methods.

\subsection{Study region}

The study region encompasses the Konza Prairie LTER station with its mission to monitor and study the impacts of climate, fire, and grazing on tallgrass prairies. Konza LTER contains 3487-ha of native tallgrass prairie located in the Flint Hills of northeastern Kansas (identified in Fig. 2). The landscape is a result of millions of years of exposure to weathering and stripping by the Kansas River's tributaries (Oviatt, 1998) and the native prairie's flora is dominated by the perennial warm-season grasses. Groundwater recharge occurs through the terrestrial grasslands and enhanced recharge occurs through ephemeral streambeds in the uplands (picture in Fig. 1b). This recharge reemerges to the surface through baseflow to perennial streams in the lowlands (picture in Fig. 1a).

Konza is located within a temperate climate with a mean annual precipitation of $0.789 \mathrm{~m} \mathrm{yr}^{-1}$ over the period of study, with precipitation of $0.835 \mathrm{~m} \mathrm{yr}^{-1}$ over all years of record with $75 \%$ falling during the growing season and $0.052 \mathrm{~m} \mathrm{yr}^{-1}$ of liquid water falling as snow (Hayden, 1998). As is common to grassland ecosystems, precipitation varies considerably, and frequent droughts are characterized by persistent, hot, dry winds from the southwest. The soils in Fig. 2 are fine textured silt loams or silty clay loams. They are thin (formed in loess overlying Permian limestone and shale, in the uplands) to moderately deep and welldrained (formed in loess, re-worked loess, colluvium, or from bedrock residuum, in lowland depressions; Ransom et al., 1998). The $5166 \mathrm{~km}^{2}$ study region shown in Fig. 2 will be adopted to place the hydrology of the $34.9 \mathrm{~km}^{2}$ Konza LTER into its regional setting.

The geologic setting of Konza is characterized by nearly horizontal alternating layers of 1-2 $\mathrm{m}$ thick thinly-bedded limestone sandwiched between 2-4 m thick shale (Macpherson, 1996). Such sandwich carbonate aquifers typically have some diffuse recharge through clastics layers with ebb and flow recharge from seasonal variations in river stage in units connected to surface water (White, 1969). This conceptualization is consistent with chemical analysis by Wood and Macpherson (2005) who show that while the principal groundwater paths in the local Kings Creek watershed are generally downward movement through Permian bedrock limestone, the dissolution of this limestone is minimal compared to weathering of more recent carbonates. Runoff events are buffered when they fill streambed 


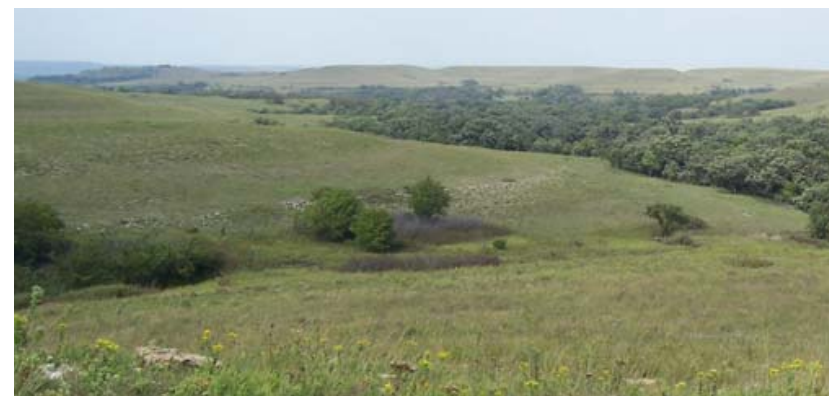

(a) Perennial streams in the lowland prairie, with the Kansas River valley in the far distance to the left.

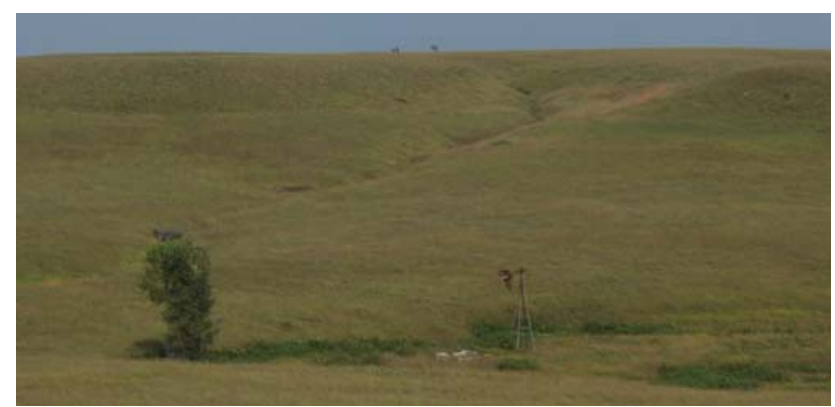

(b) Ephemeral streams in the upland prairie.

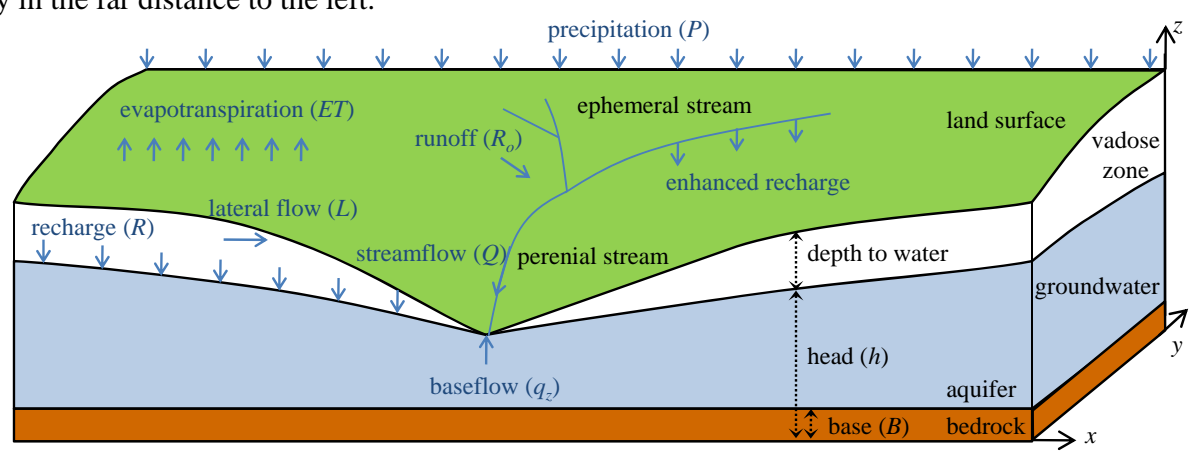

(c) Conceptual model and variables.

Fig. 1. Hydrologic processes and properties: precipitation either returns to the atmosphere through evapotranspiration, recharges groundwater in the aquifer, or contributes to streamflow through surface runoff. Groundwater recharge over the terrestrial prairie ecosystem and enhanced recharge beneath ephemeral streams in the uplands provides baseflow to perennial streams in the lowlands.

alluvium, colluvium and near channel fractured limestone and gradually release this storage to streamflow and hyporheic flow through streambed gravels. Gauging stations on small ephemeral watersheds illustrate that the fraction of precipitation that flows within a stream channel varies considerably both spatially and temporally from less than $1 \%$ to almost $40 \%$ (Dodds et al., 1996).

A conceptual model of the hydrologic system and important surficial and groundwater properties are identified in Fig. 1c. A hydrologic water budget at the surface is provided by precipitation equaling evapotransportation plus surface water runoff plus recharge to groundwater. A vegetation model is used to study these surficial processes and their variability over climate and soil properties. The long-term hydrogeological water budget is satisfied by recharge equaling baseflow from groundwater to streams and rivers. A groundwater model is used to study these subsurface processes and the occurrence of ephemeral and perennial streams.

The purpose of this study is not to quantify the seasonal and interannual forcings of bank storage and hyporheic flow, but to study long-term sustained fluxes through groundwater and baseflow to streams, and how the properties of streambeds control groundwater/surface water interactions. Long-term averages over $21 \mathrm{yr}$ of simulation are used to substantiate the role of groundwater in such surficial fluxes.

\subsection{Ecohydrologic processes}

Surficial hydrologic processes are studied using the USDA's EPIC (Erosion Productivity Impact Calculator) model as documented by Sharpley and Williams (1990). Conservation of mass is expressed using the variables in Fig. 1 as

$P=\mathrm{ET}+R_{o}+R+L+\Delta S$

where $P$ is precipitation, ET is evapotranspiration, $R_{o}$ is runoff, $R$ is the recharge rate, $L$ is lateral throughflow and interflow through soils, and $\Delta S$ is short-term changes in storage in soil layers. While the EPIC model is executed on daily increments where the buffering of water in storage is important in properly partitioning fluxes, the changes in storage is negligible when computing long-term fluxes over the period of study, and

$\Delta S=0$.

The evapotranspiration, runoff and recharge are all computed using the methods described below and lateral flow is computed to close the water balance in Eq. (1).

Runoff is estimated using the curve number method as a function of precipitation amount, surface soil water content and slope of the soil (USDA, 2004). Percolation between up to ten soil layers occurs as water moves from a soil layer 


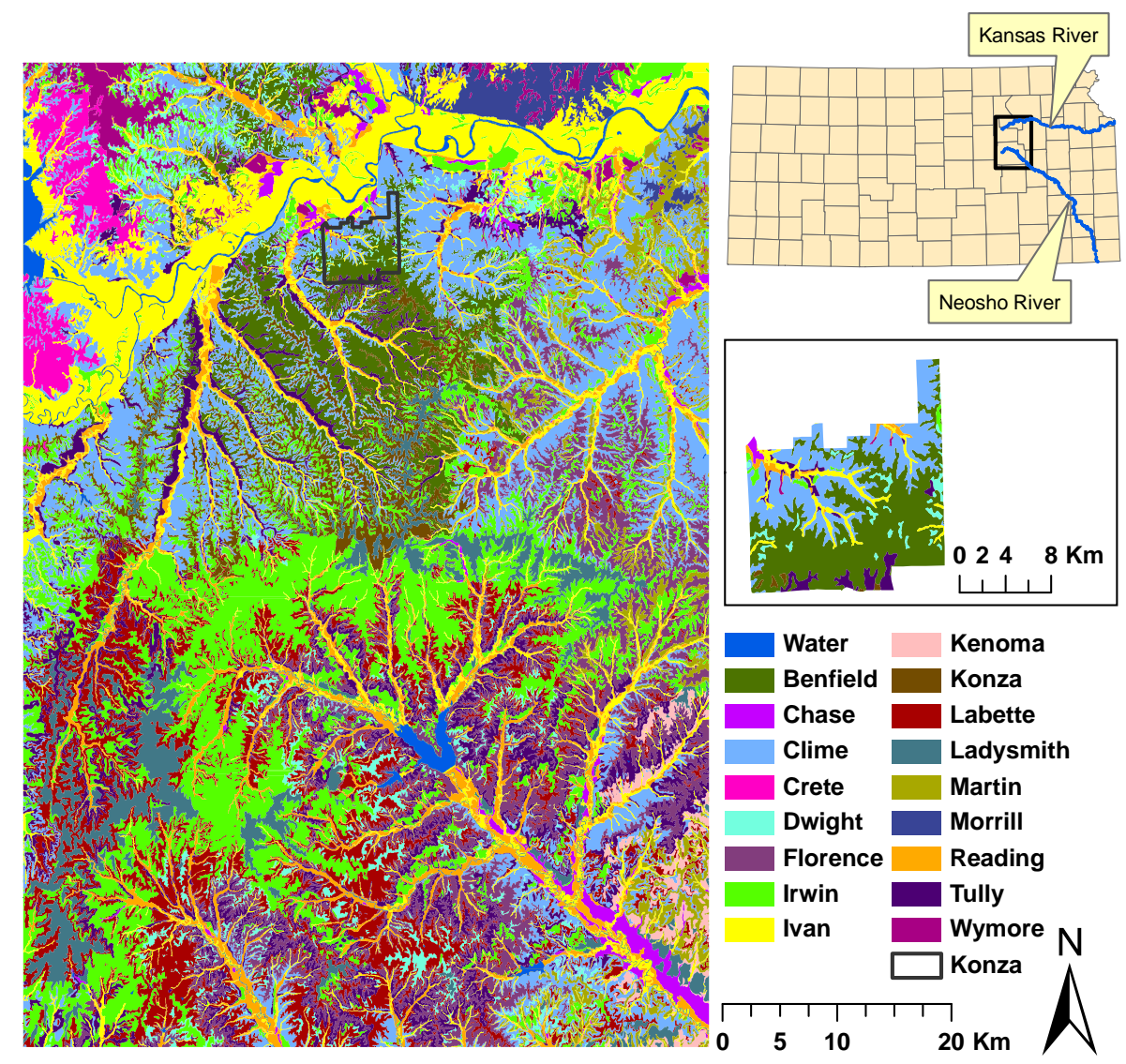

Fig. 2. Soils in the Konza study region.

to the underlying layer at soil water contents of field capacity and higher and lateral flow is based upon percolation and field slope. Recharge to groundwater occurs from deep drainage below the root zone when the entire soil profile is at field capacity. Soil water content is estimated using the Ritchie method and is based on sand, silt, clay and organic matter percentages and bulk density (Sharpley and Williams, 1990).

EPIC has the options to use five different potential evapotranspiration models and four different soil storage mechanisms (Benson et al., 1992). The ET models include Hargreaves, Modified Hargreaves, Priestly-Taylor, Penman, and Penman Monteith. When compared with three other potential soil storage and drainage methods, the Ritchie method resulted in the lowest soil water storage. However, despite the range of differences reported for potential evapotranspiration and soil water content methods, Benson et al. (1992) concluded that environmental inputs and weather data had a much greater influence on water use and drainage. The efficacy of the EPIC model to deal with water, drainage, weather and management practices is well documented by the 13000 EPIC runs of 100 simulation years that were conducted across the entire USA for testing and application to address the 1977 Resources Conservation Act (Williams, 1990).

The EPIC model was applied to each of the polygons in Fig. 2, which have uniform soil properties and soil slope. The surface area of these polygons are on the order of 1$2 \mathrm{~km}^{2}$ (or larger), a size that was considered by Famiglietti and Wood (1995) to be a REA (Representative Elementary Area) for the Kings Creek catchment basin on Konza. At spatial scales larger than the REA, models which use spatially averaged patterns of dominant processes (root zone moisture content, soil properties, vegetation, solar radiation) provide consistent results with fully spatially distributed simulations. This finding is consistent with Brunsell et al. (2008) who employed remote sensing data at various scales and concluded that polygons on the order of $2 \mathrm{~km}$ are sufficient to characterize the spatial characteristics of evapotranspiration observed in the Konza LTER region.

The site-specific data used in the EPIC model are described in Table 1 . The same daily weather variables were used for each soil polygon in EPIC and the model was evaluated over climatic data from 1985-2005. While time series emerge for runoff, recharge and evapotranspiration based upon the precipitation and other variables, results are 
Table 1. Grassland prairie model parameters.

\begin{tabular}{ll}
\hline Model Parameter & Value/Source \\
\hline Climate: & Kansas Weather Data Library (2011) \\
Soils (Fig. 2): & USDA (2011) \\
$\begin{array}{c}\text { Management practices: } \\
\text { burning schedule }\end{array}$ & March each year \\
grazing up to (20\%) & June each year \\
grazing up to (95\%) & August each year \\
$\quad$ irrigation codes & Dry land \\
Vegetation type: & Range; Dodds et al. (1996) \\
\hline
\end{tabular}

summarized annually and eventually averaged over the historical records to give long-term sustained recharge $R$ for input to the groundwater model. While the daily time steps of EPIC may miss extreme runoff events for short duration precipitation events, the ability of EPIC to reproduce field measurements of mean annual runoff has been substantiated by Wang et al. (2006).

\subsection{Hydrogeologic processes}

A groundwater model is developed to study the movement of recharge through the aquifer system in Fig. 1 and its reemergence as surficial baseflow to streams and rivers. A mathematical description for steady two-dimensional groundwater flow with recharge is given by

$$
\frac{\partial}{\partial x}\left[k(h-B) \frac{\partial h}{\partial x}\right]+\frac{\partial}{\partial y}\left[k(h-B) \frac{\partial h}{\partial y}\right]=-R
$$

where $h$ is the groundwater elevation and $B$ is the elevation of the base of the aquifer. While the groundwater in this study flows through thin horizontal layers of alternating limestone and shale (Macpherson, 1996), the approach adopted for this regional study is to model the layered medium as an anisotropic medium where $k$ is the equivalent anisotropic hydraulic conductivity of the aquifer system (Bear, 1972, Sect. 5.8). While this assumption does not partition the horizontal components of specific discharge within individual layers, it does correctly reproduce the vertically integrated specific discharge across all layers, and such a one-layer model was previously adopted in the nearby Mill Creek watershed by York et al. (2002).

The interaction between groundwater and surface water is modeled using Darcy's Law

$q_{z}=\frac{h-h^{*}}{c}, \quad c=\frac{D^{*}}{k^{*}}$

where $q_{z}$ is the vertical component of the specific discharge, $c$ is the resistance of the streambed sediments, and $h^{*}$ is the elevation of the surface water. The resistance is related to the depth $D^{*}$ and hydraulic conductivity $k^{*}$ of the streambed

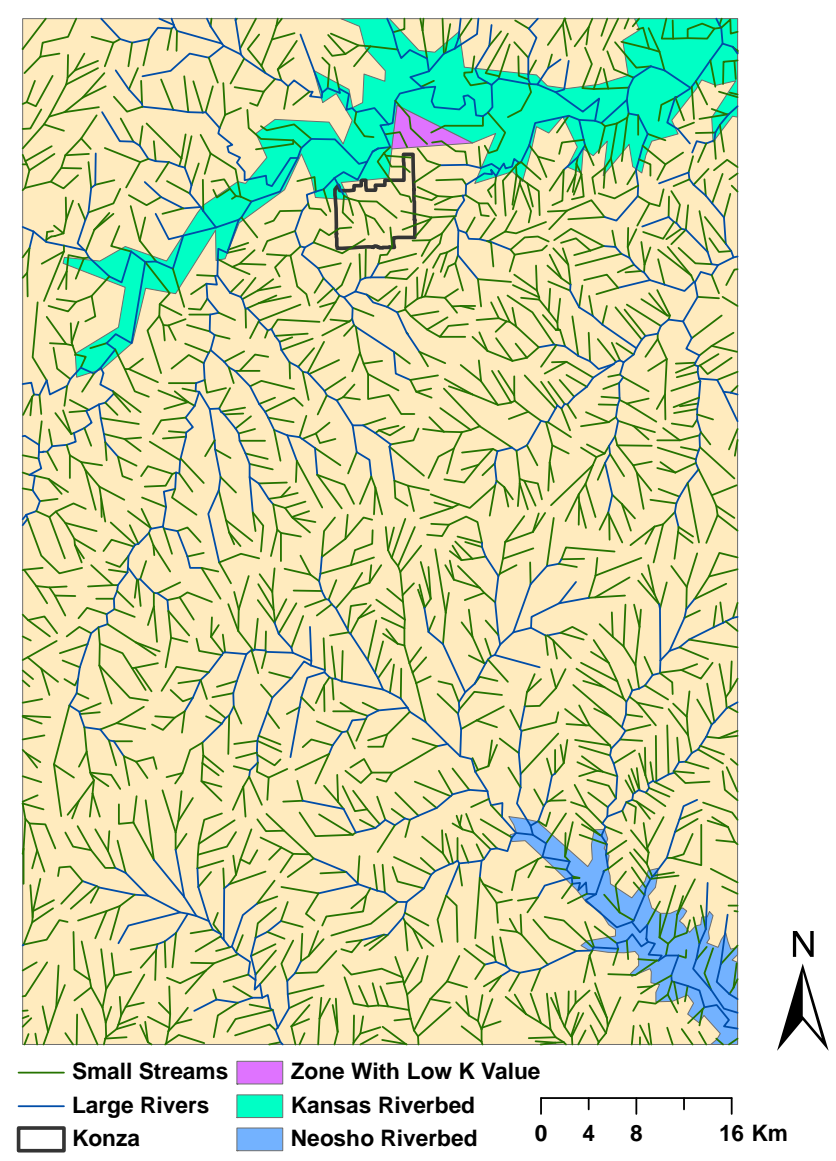

Fig. 3. Streams, river channels, and low conductivity zone.

sediments. The enhanced recharge beneath surface water to groundwater is obtained by integrating this specific discharge over the horizontal surface area (Haitjema et al., 2001)

$Q_{\mathrm{er}}=\int_{0}^{L} w q_{z} \mathrm{~d} s \quad\left(q_{z}<0\right)$

with width $w$ and length $L$ for stream reaches where the groundwater elevation is less than surface water, Likewise, baseflow from groundwater to surface occurs beneath stream reaches where the elevation of the groundwater is greater than the stream

$Q_{\mathrm{bf}}=\int_{0}^{L} w q_{z} \mathrm{~d} s \quad\left(q_{z} \geq 0\right)$.

The groundwater flow equations are computationally implemented in Modflow (McDonald and Harbaugh, 1988). The governing Eq. (3) is solved using finite differences with cell sizes of $150 \mathrm{~m}$ and the model domain contains 400 columns by 574 rows of cells. The stream network is illustrated in Fig. 3 and was obtained from the USGS's National Hydrography Dataset.

The data sources for other variables are summarized in Table 2 . The groundwater elevation is specified at the boundary 


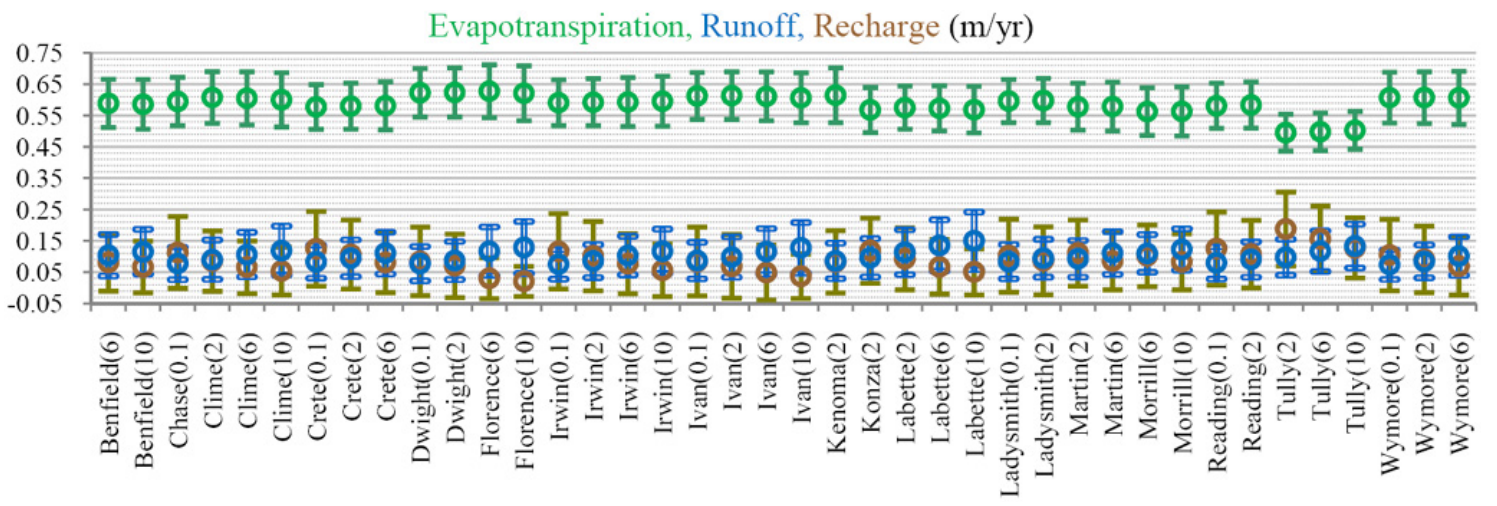

Fig. 4. Mean estimates for evapotranspiration, runoff, and recharge plus and minus one standard deviation for the soils of the study region.

of the model domain to be $20 \mathrm{~m}$ below land elevation, and the USGS's DEM data is also used to specify the surface water elevation for streams and rivers. This boundary condition reproduces previous regional modeling results in an infinite domain (Yang et al., 2010), and the size of the model domain was chosen such that model predictions at Konza were not significantly changed by further enlarging the model domain.

Surface water segments are classified as large rivers with low resistance levels (essentially setting groundwater elevation equal to that of the surface water) or as small streams where the model was run over a range of possible values of resistance. Each cell in Modflow uses the average recharge rate obtained from the EPIC model results. A range of hydraulic conductivity is specified and PEST is used to obtain the values that best matched a set of groundwater elevation measurements from observation wells about the Konza LTER region. The model results are exported to ArcMap and zonal statistics are used to compute the enhanced recharge Eq. (5) and baseflow Eq. (6) between groundwater and surface.

\section{Results}

Partitioning of surficial hydrologic fluxes was studied using the EPIC model. While the mean precipitation over the period of study (1985-2005) is $0.789 \mathrm{~m} \mathrm{yr}^{-1}$ there is great variability in both the total yearly precipitation (between $0.452 \mathrm{~m}$ in 1988 and $1.292 \mathrm{~m}$ in 1993) and the timing of rainfall events. The surficial fluxes were evaluated over the historical climate data for all soils in Fig. 2 and results were further classified by average soil slope as $0.1,2,6$ or $10 \%$ using USDA (2011). Results are presented in Fig. 4 for the soils and slopes of the study region, showing the mean annual fluxes for evapotranspiration, runoff and recharge across the study period. Similar to a study of runoff and recharge by Batelaan and De Smedt (2007) in The Netherlands and Belgium, the temporal variability of each flux is indicated using error bars at plus and minus one standard deviation about the mean.
Table 2. Hydrogeology model parameters.

\begin{tabular}{ll}
\hline Model Parameter & Value \\
\hline Elevation: & \\
Base $(B)$ & $250 \mathrm{~m}$ \\
Top & $450 \mathrm{~m}$ (unconfined) \\
Head specified $(h)$ boundary & $20 \mathrm{~m}$ below DEM \\
Hydraulic conductivity $(k)$ & \\
Konza region & $10^{-2}-100 \mathrm{~m} \mathrm{~d}^{-1}$ \\
low $k$ zone & $10^{-5}-10 \mathrm{~m} \mathrm{~d}^{-1}$ \\
Kansas River alluvium & $10^{-3}-50 \mathrm{~m} \mathrm{~d}^{-1}$ \\
Neosho River alluvium & $24 \mathrm{~m} \mathrm{~d}^{-1} ;$ Yang et al. (2010) \\
Recharge $(R)$ & Values from grassland model \\
Resistance $(c)$ of streambed: & \\
small streams & $100,1000,10000,100000$ day \\
Kansas and Neosho Rivers & $<1$ day \\
Stream network & USGS (nhd.usgs.gov) \\
\hline
\end{tabular}

It should be noted that the information provided by these results differs from previous investigations and yet are substantiated in their findings. Famiglietti et al. (1992) and Famiglietti and Wood (1994) developed daily models of evapotranspiration that hypothesized the importances of soil water storage and established the size of REAs that were used here. Gutowski Jr. et al. (2002) developed hydrologic models over a $9 \mathrm{yr}$ period of simulation (1985-1994) that partitioned precipitation into evapotranspiration and groundwater recharge, and suggested that future models should include surface water runoff.

The soils in the Konza region were classified by Ransom et al. (1998) from lowlands to uplands as located on: floodplains and terraces, foot slopes, side slopes, and interfluves and benches. The floodplains and lowland terraces are covered by Ivan soil on Konza which are deep, moderately well drained and moderately permeable. Other floodplain soils in the region include Chase, Ladysmith, and Reading. Tully soil in the foot slopes are formed from hillslope sediments and 

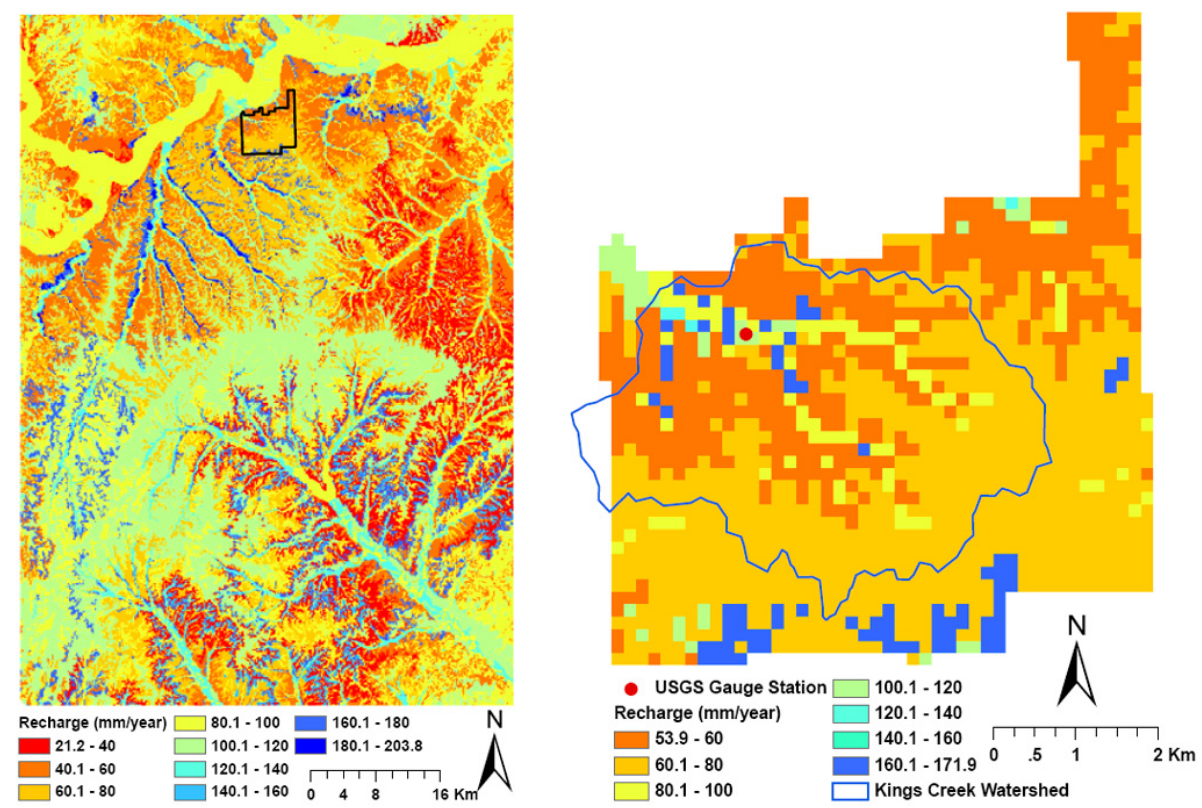

Fig. 5. Spatial distribution of recharge in the study region and at Konza LTER.

alluvial-colluvial deposits and are thicker with highest clay and rock fragment content in the lower part of the subsoil. Soils of the side slopes are thinner gravelly silty clays with the most common Konza soils being Benfield and Clime. Side slope soils of the region include Crete, Irwin, Kenoma, Martin, Morill, and Wymore. Soils of the interfluves and summit benches are Konza, Dwight, Florence and Labette with silty clay texture.

The results in Fig. 4 illustrate that mean evapotranspiration (ET) ranges across soils and slopes from 0.495$0.627 \mathrm{~m} \mathrm{yr}^{-1}$, with most soil/slope groups having mean values within \pm 1 standard deviation of the other soils. The exception is Tully soil, which has the lowest evapotranspiration rate, and which is the only major soil group located on the foot slopes. The mean surface runoff $\left(R_{O}\right)$ varies between $0.074-0.150 \mathrm{~m} \mathrm{yr}^{-1}$ and consistently shows higher rates of runoff as the slope of the soil surfaces increases across a group with the same soil type. The mean rate of recharge $(R)$ varies between $0.021-0.187 \mathrm{~m} \mathrm{yr}^{-1}$ and the error bar at 1 standard deviation falls below $0 \mathrm{~m} \mathrm{yr}^{-1}$, which is consistent with results in Batelaan and De Smedt (2007) and indicates that a different statistical distribution such as log normal may better capture the variability of recharge across time. Results indicate that higher rates of recharge (and higher variability in standard deviation) occur for parcels with lower slopes. The spatial distribution of average recharge is illustrated in Fig. 5. For a given soil type, recharge is larger where the slope is relatively flat, which occurs at Konza in the river valley and foot slopes of Kings Creek and to the south on benches between terraces (see photos in Fig. 1a and b). Likewise, lower recharge rates occur when the soil slope is steeper, which occurs on the side slopes. These patterns that exist at Konza are observed across the soil types and slopes in the region.

The average rates of evapotranspiration, runoff, and recharge were computed both for Konza and the regional study region by spatially averaging their values across the soil types and slopes. Results are presented in Table 3, where the percent area of each soil type/slope group was multiplied by these rates and then summed. When results are presented as fractions of precipitation, the results at Konza are $\mathrm{ET} / P=74.6 \%, R_{o} / P=14.3 \%, L / P=2.2 \%$, and $R / P=8.9 \%$ and values for the region are $\mathrm{ET} / P=74.7 \%$, $R_{o} / P=13.3 \%, L / P=1.4 \%$, and $R / P=10.6 \%$. These results are consistent with the findings in Fig. 4 where less recharge occurs at Konza than the region since soils have steeper slopes, and evapotranspiration is fairly uniform between Konza and the region.

Subsurface groundwater flow and the interactions between groundwater and surface water in streams and rivers was studied using the Modflow model. A steady model was developed to study long-term flow rates using the spatial distribution of average recharge from the terrestrial ecosystem in Fig. 5. The aquifer domain was subdivided into the alluvial plains associated with the Kansas and Neosho Rivers, and the limestone and shale units in the Flint Hills. A small zone is identified in Fig. 6 with a lower conductivity than the rest of the carbonate aquifer. This lower conductivity zone is required for the model to accurately match the observed water level elevation in a set of wells.

The location of the observation wells is also identified in Fig. 6 along with the difference in elevation between the modeled and observed groundwater level at each well. Five wells are from the Kansas WIZARD observation well 


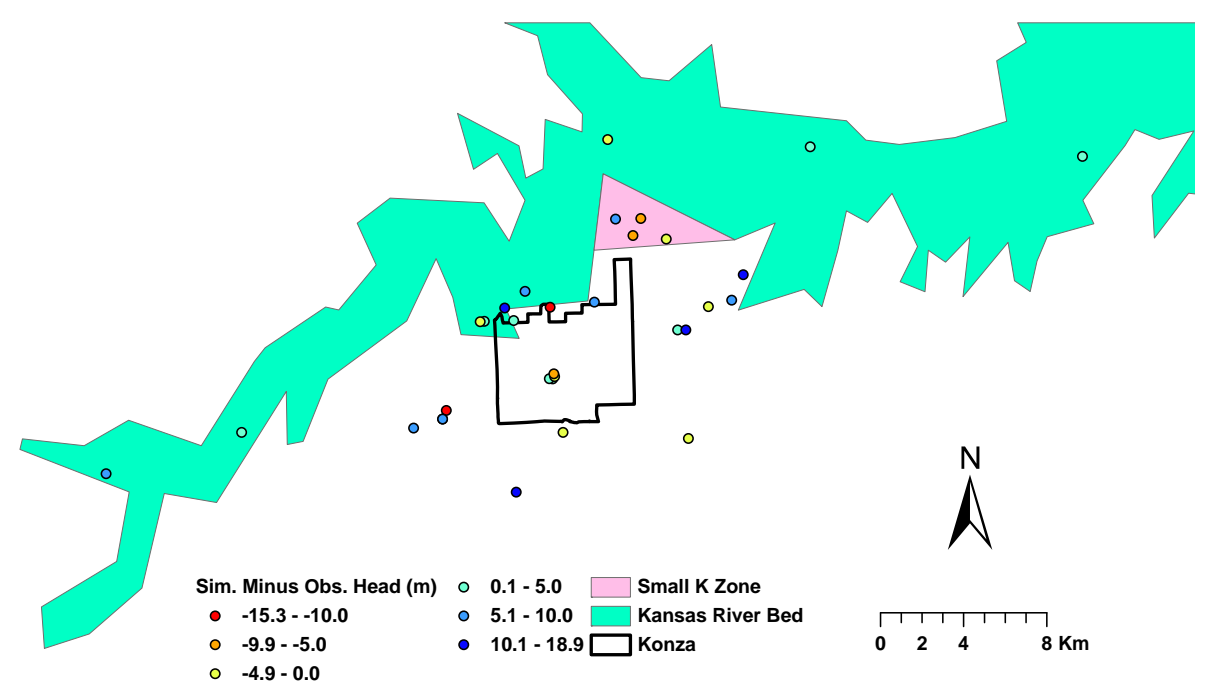

Fig. 6. Groundwater observation wells and differences between simulated and observed heads.

database, which contain wells periodically measured by the Kansas Geological Survey and the USGS. The location of twenty three wells are identified in the Kansas WWC5 water well completion records. Additionally, two more were identified in Lauwo (2007) and two other wells on Konza were measured including the well beneath the windmill shown in Fig. 1b. These wells are largely screened in or connected to the Morrill Limestone unit studied by Macpherson (1996). The relatively large number of observation wells and their placement in both the Kansas River valley and the Flint Hills helps substantiate the findings of this study (e.g. only three observation wells in the Kansas River valley were used by York et al., 2002).

As discussed earlier, a range of values for the hydraulic conductivity were specified individually for the Kansas and Neosho River valleys, the Konza Flint Hills region, and the low hydraulic conductivity zone and PEST was used to find the three values that best satisfied the measured values in the observation wells. The values of resistance of the streambeds beneath the upland and lowland prairie streams was also unknown. For this study, a single value of resistance was specified for all these streams that took on values of 100, 1000, 10000 , or 100000 days and PEST calibration was performed for each of these four values. The actual value of resistance at Konza will be chosen later by matching the enhanced recharge (Eq. 5) in the ephemeral streams and the baseflow (Eq. 6) in the perennial streams.

The calibrated values of hydraulic conductivity for each scenario and the mean and root mean square error are presented in Table 4. These results are consistent with those presented by York et al. (2002) who used a value of $k=2 \times 10^{-5} \mathrm{~m} \mathrm{~s}^{-1}=1.7 \mathrm{~m} \mathrm{day}^{-1}$ for the nearby Mill Creek watershed and it was suggested that this value was too high (York et al., 2002, p.232). The groundwater elevation in Fig. 7 illustrate the mound that forms between the Kansas and Neosho Rivers as well as the general southeast to northwest flow direction beneath Konza.

Note that the model results indicate that only small changes in conductivity and RMSE in Table 4 occur when the streambed resistance changes from $100000 /$ day to $10000 /$ day. As the streambed resistance takes on values of 1000 /day to 100 /day the surface water interactions through streambeds begin to noticeably change calibrated values of hydraulic conductivity.

The depth to groundwater was computed by subtracting the land elevation from the groundwater elevation and is illustrated in Fig. 8. Regionally, the depth to water illustrates recharge zones in the hills, discharge zones in the streams, and shallow depth to water in the floodplains and valleys of the Kansas and Neosho Rivers. These results provide a good match with field observations where baseflow becomes established downriver from the gauging station (identified in Fig. 5) which is dry most of the year (Dodds et al., 1996). These figures illustrate conditions when resistance is 100000 days.

While the hydraulic conductivity of the aquifer clearly varies over possible values of streambed resistance in Table 4 , the resistance also strongly influences the exchange of water between groundwater and surface water stores. This was quantified in the Kings Creek watershed by computing enhanced recharge $Q_{\text {er }}$ using Eq. (5) beneath the portions of the watershed where depth to water was positive in Fig. 8, and by computing baseflow $Q_{\text {bf }}$ using Eq. (6) beneath the portions of the watershed where depth to water was negative. The results are presented for each value of resistance in Fig. 9.

When the results for enhanced recharge and baseflow through streambeds is plotted as a function of streambed resistance on log-log axes in Fig. 9, it suggests that this functional relation takes on a linear form for this watershed. Least 
Table 3. Average recharge on Konza and the region by spatially averaging over the flood plains and terraces, foot slopes, side slopes, and benches and interfluves. Note that soil names are colored in the first column to help identify their position in the landscape.



squares regression was applied to develop the best fit straight line, giving cumulative enhanced recharge in the ephemeral stream of the uplands

$\log Q_{\mathrm{er}}=6.217-0.814 \log c$

and cumulative baseflow in perennial stream of the lowlands

$\log Q_{\mathrm{bf}}=4.356-0.895 \log c$.
Note that the dots are plotted at the model results and the straight line is the best fit line from regression.

\section{Discussion: water balance and geological properties}

This study quantifies the partitioning of mean annual precipitation into evapotranspiration, runoff and recharge. Model results in Table 3 forecast that approximately $75 \%$ of 

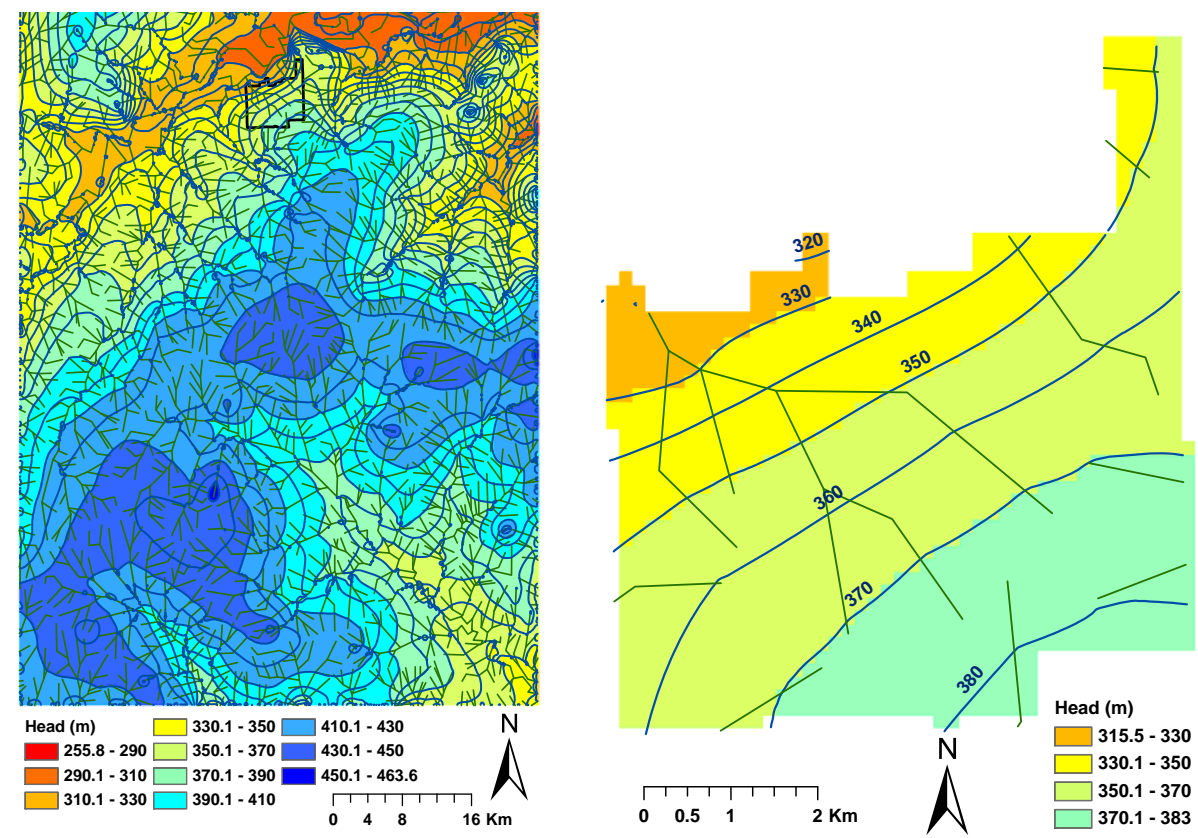

Fig. 7. Groundwater elevation in the study region and at Konza LTER.


Fig. 8. Depth to water in the study region and at Konza LTER.

preciptation becomes evapotranspiration at both Konza and the region. Spatial averages of runoff over the land surface plus lateral throughflow and interflow through the soils is between $14-17 \%$ of precipitation with larger values occuring in the steeper slopes of Konza. Groundwater recharge is $9 \%$ at Konza and $11 \%$ regionally. These recharge rates are consistent with statewide predictions for Kansas by Hansen
(1991) who estimated groundwater recharge to be approximately $10 \%$ of precipitation in the Konza region. Findings are also consistent with and extend results by Gutowski Jr. et al. (2002) who partitioned precipitation in the Konza region into $88 \%$ evapotranspiration and $12 \%$ recharge while ignoring surface water runoff. Gutowski Jr. et al. (2002) also suggested that the use of a Modflow groundwater model 
Table 4. Groundwater parameter estimation.

\begin{tabular}{lrrlcc}
\hline $\begin{array}{l}\text { Resistance } \\
(\text { day })\end{array}$ & $\begin{array}{r}k \text { Konza } \\
\left(\mathrm{m} \mathrm{day}^{-1}\right)\end{array}$ & $\begin{array}{r}k \text { Kansas River } \\
\left(\mathrm{m} \mathrm{day}^{-1}\right)\end{array}$ & $\begin{array}{l}\text { Low } k \text { zone } \\
\left(\mathrm{m} \mathrm{day}^{-1}\right)\end{array}$ & $\begin{array}{c}\text { Mean error } \\
(\mathrm{m})\end{array}$ & $\begin{array}{c}\text { RMSE } \\
(\mathrm{m})\end{array}$ \\
\hline 100000 & 0.69 & 3.91 & 0.049 & 2.44 & 8.24 \\
10000 & 0.82 & 4.04 & 0.054 & 2.45 & 7.98 \\
1000 & 2.05 & 8.08 & 0.10 & 2.06 & 7.74 \\
100 & 14.30 & 47.33 & 0.62 & 2.02 & 7.74 \\
\hline
\end{tabular}

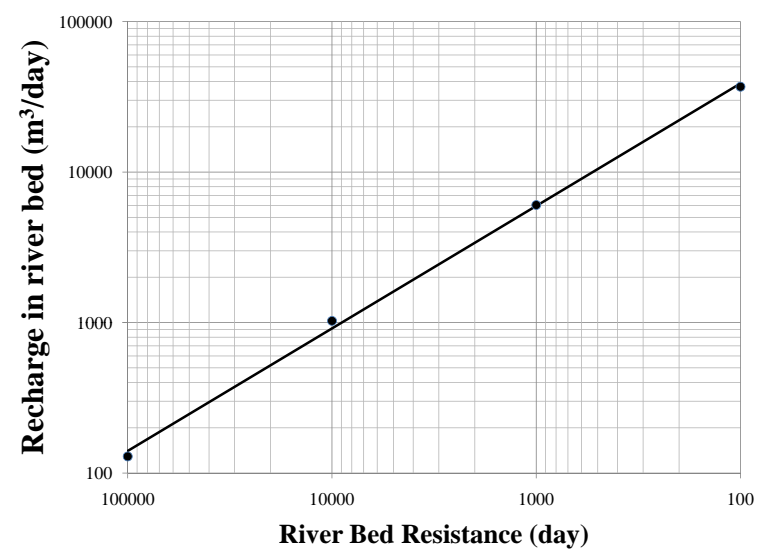

(a) Cumulative recharge from ephemeral streams to groundwater in the uplands.

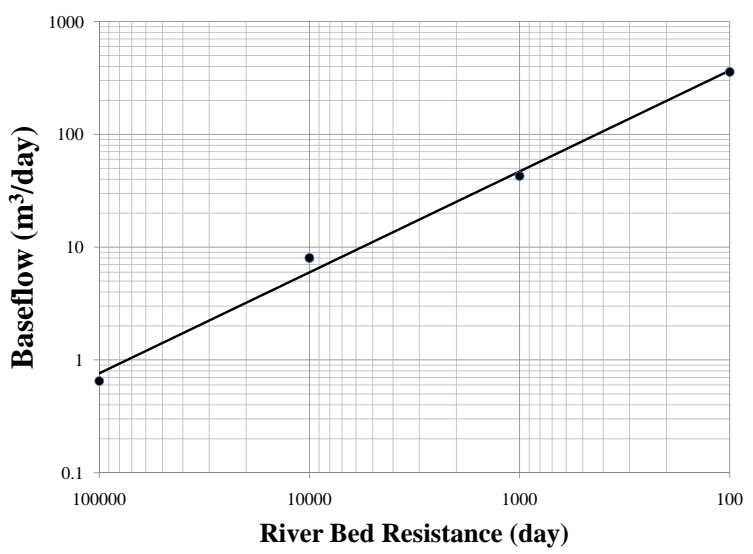

(b) Cumulative baseflow from groundwater to perennial streams in the lowlands.

Fig. 9. Groundwater and surface water interactions in the Kings Creek watershed and their dependence upon the streambed properties.

would support better agreement between surface water and groundwater, which was done here.

Surface water fluxes may be computed for the $16.02 \mathrm{~km}^{2}$ Kings Creek watershed identified in Fig. 5, which largely lies inside the Konza LTER. The average discharge at the
USGS gauging station in this figure during 1985-2005 is $5430 \mathrm{~m}^{3}$ day $^{-1}\left(2.22 \mathrm{ft}^{3} \mathrm{~s}^{-1}\right)$. This gauging station is dry throughout most of the year and baseflow occurs further downstream. The EPIC predictions of surface water runoff across the catchment is $4960 \mathrm{~m}^{3}$ day $^{-1}$ $\left(16.02 \mathrm{~km}^{2} \times\left(1000 \mathrm{~m} \mathrm{~km}^{-1}\right)^{2} \times 0.1131 \mathrm{~m} \mathrm{yr}^{-1} \times \mathrm{yr} / 365\right.$ day) and lateral flow through the soils contributes $750 \mathrm{~m}^{3}$ day $^{-1}$.

It appears that stream loss through enhanced recharge in the ephemeral streams is small and likely on the order of $100 \mathrm{~s}$ of $\mathrm{m}^{3} \mathrm{day}^{-1}$, given the input to streams is $4960 \mathrm{~m}^{3}$ day $^{-1}$ of runoff plus a portion of $L=750 \mathrm{~m}^{3}$ day $^{-1}$ and average stream discharge at the gauging station is $Q=5430 \mathrm{~m}^{3}$ day $^{-1}$. This result is consistent with findings by Jordan (1977) in western Kansas who interpreted data from stream gauging stations to find that transmission losses through stream channels accounts for $2 \%$ of flow per mile of stream in western Kansas but that much of this returned from bank storage to streamflow, and stated that transmission losses of high flows are uncommon or nonexistent in eastern Kansas. This result is also consistent with Dodds et al. (1996) who partitioned surface runoff into $1 / 3$ runoff in the stream and the remaining $2 / 3$ flowed through shallow groundwater and the hyperheic zone and much of this eventually reimmerges from bank storage to streamflow, with only small transmission losses to deeper groundwater. While phreatophytes in southcentral Kansas may extract groundwater at a rate of $0.4 \mathrm{~m} \mathrm{yr}^{-1}$ times the canopy area (Steward and Ahring, 2009), it is likely that they do not contribute significantly to the hydrologic water budget at Konza. The resistance of streambed sediments may be obtained from Fig. 9. In the upland ephemeral stream channels, enhanced recharge on the order of $100 \mathrm{~s}$ of $\mathrm{m}^{3}$ day $^{-1}$ gives a streambed resistance in Fig. 9a on the order of 100000 days. Measured baseflow at the outlet of the catchment during dry seasons when phreatophytes are dormant suggests that sustained baseflow is on the order of $50 \mathrm{~m}^{3} \mathrm{day}^{-1}$. Since groundwater recharge across the Kings Creek watershed is $3070 \mathrm{~m}^{3}$ day $^{-1}$ $\left(16.02 \mathrm{~km}^{2} \times\left(1000 \mathrm{~m} \mathrm{~km}^{-1}\right)^{2} \times 0.0700 \mathrm{~m} \mathrm{yr}^{-1} \times \mathrm{yr} / 365\right.$ day), approximately $2 \%$ of the quantity of average recharge flows as baseflow in Kings Creek (although the actual source of this baseflow may be derived from recharge far 
to the south which flows towards the Kansas River). Since baseflow is on the order of $50 \mathrm{~m}^{3} \mathrm{day}^{-1}$, the streambed resistance in the perennial lowlands is on the order of 1000 days in Fig. 9b. This resistance value is consistent with Macpherson and Sophocleous (2004) who measured local sediments in the Kings Creek floodplain to be $8-10 \mathrm{~m}$ thick with a hydraulic conductivity of $3 \times 10^{-3} \mathrm{~m} \mathrm{day}^{-1}$, giving resistance of 2600-3300 days using Eq. (4). This suggests that the net enhanced recharge in the ephemeral stream reaches is on the same order as the net baseflow in ephemeral stream reaches. Results also suggest that future models may differentiate between the resistance controlling groundwater/surface water exchange in ephemeral (higher resistance) vs. perennial streams (lower resistance).

The geological properties of the aquifer in Table 4 may be inferred from the values of resistance found in the streambed channels. This gives values of hydraulic conductivity of $k=1-2 \mathrm{~m} \mathrm{day}^{-1}$ on Konza, $k=0.05-0.1 \mathrm{~m} \mathrm{day}^{-1}$ in the low permeability zone, and $k=4-8 \mathrm{mday}^{-1}$ in the local Kansas River valley. It should be noted that the Kansas River is the only river that incises the Flint Hills from west to east; other rivers originate in the Flint Hills and flow either west or east. A possible geomorphological rationale for this may be that the mantle contains more highly erodible material in this portion of the Flint Hills. The lower conductivity zone identified in this study corresponds to a narrowing of the Kansas River valley and suggests the bedrock in the low-conductivity zone is more resistant to erosion than bedrock to the northeast or southwest. The resistant zone may have played a role in the more northerly location of historic channels of the Kansas River (Beck, 1961).

Model calibration was performed to determine the:

- Hydraulic conductivity of the three zones identified in Fig. 3, and

- resistance of streambeds

such the model reproduced the:

- Observed groundwater elevations in Fig. 6,

- net discharge from surface water to groundwater through the ephemeral streambeds of the Kings Creek watershed in Eq. (5) and found to be on the order of $100 \mathrm{~s} \mathrm{of} \mathrm{m}^{3}$ day $^{-1}$ from conservation of mass of surface waters, and

- net discharge of groundwater to surface water as baseflow in perennial streambeds of Kings Creek watershed in Eq. (6) and found to be on the order of $50 \mathrm{~m}^{3} \mathrm{day}^{-1}$ from field observation.

Our calibration method specifies the value of resistance to a set of representative values and then solves the model at each fixed value by letting PEST find the best values of hydraulic conductivity to match observation heads in Table 4 . For each of these simulations we then integrated enhanced recharge and baseflow, graphed the observed groundwater/surface water fluxes in Fig. 9, and picked off the values of resistance that best matched observed discharges. To our knowledge, this is the first time this approach has been used to establish resistance of streambeds.

\section{Conclusions}

This study examines hydrologic fluxes in an important LTER region covered by native prairie. A surficial model was employed to partition long-term precipitation into surface water runoff, recharge to groundwater, and lateral flow through soils. The groundwater recharge was incorporated with interactions across the groundwater/surface water interface in stream channels to study hydrologic processes. The specific computational tools employed here are the USDA's EPIC model and the USGS's Modflow model.

Surficial fluxes were computed for the soils identified in Fig. 2 over observed slopes of the land surface and results are presented in Fig. 4. The spatial distribution of average recharge is shown in Fig. 5 along with the location of the local Kings Creek watershed and a USGS gauging station. The spatial distribution of surficial fluxes are presented in Table 3 for Konza and the region. A groundwater model was calibrated using the observation wells in Fig. 6 and the stream network in Fig. 3. The resulting groundwater elevation and depth to water are illustrated in Figs. 7 and 8. While the resistance of the streambed channel sediments was unknown, the model was run over a range of possible values and the resulting aquifer properties are shown in Table 4. Relations were developed between resistance and enhanced recharge in the uplands in Eq. (7) and baseflow in the lowlands Eq. (8) and shown in Fig. 9.

This study extends previous investigations by fully partitioning precipitation into evapotranspiration, runoff, recharge, and lateral flow through soils in the Konza region. The resulting spatial distribution of recharge was incorporated into a Modflow groundwater model, which was also suggested by previous investigations. The hydrologic water budget for this study substantiates the discharge of enhanced recharge beneath upland ephemeral streams as well as the baseflow contribution to lowland perennial streams. A new $\log -\log$ relation between these fluxes and streambed resistance was developed here and used to quantify the properties of streambed sediments. This in turn enabled interpretation of the hydraulic conductivity of aquifer media based upon the streambed resistance.

The methodology put forth here to study hydrologic fluxes in a native prairie ecosystem are extensible to other biomes and regions of the world. As are the methods used to related riverbed resistance to hydrologic fluxes. This study provides a baseline hydrologic assessment of the Konza LTER 
and region and provides a framework to study the impacts of climatological and other forcings on the system.

Acknowledgements. The author gratefully acknowledges financial support provided by the National Science Foundation (grants EPS0553722 and GEO0909515), the United States Department of Agriculture/Agriculture Research Service (Cooperative Agreement 58-6209-3-018), and the Provost Office's Targeted Excellence Program at Kansas State University.

Edited by: Y. Fan

\section{References}

Batelaan, O. and De Smedt, F.: GIS-based recharge estimation by coupling surface-subsurface water balances, J. Hydrol., 337, 337-355, 2007.

Bear, J.: Dynamics of fluids in porous media, Dover Publications, New York, 1972.

Beck, H. V.: A buried valley northwest of Manhattan, Kansas, in: Geological Survey Research, Professional Paper 424-D of Short papers in the geological and hydrologic sciences, articles 293435, D182-D185, USGS, 1961.

Benson, V. W., Potter, K. N., Bogusch, H. C., Goss, D., and Williams, J. R.: Nitrogen leaching sensitivity to evapotranspiration and soil water storage estimates in EPIC, J. Soil Water Conserv., 47, 334-337, 1992.

Brunsell, N. A., Ham, J. M., and Owensby, C. E.: Assessing the multi-resolution information content of remotely sensed variables and elevation for evapotranspiration in a tall-grass prairie environment, Remote Sens. Environ., 112, 2977-2987, 2008.

Collins, S. L., Knapp, A. K., Hartnett, D. C., and Briggs, J. M.: The dynamics of tallgrass prairie synthesis and research opportunities, in: Grassland Dynamics: Long-Term Ecological Research in Tallgrass Prairie, edited by: Knapp, A. K., Briggs, J. M., Hartnett, D. C., and Collins, S. L., Chapt. 17, Oxford University Press, 1998.

Dodds, W. K., Blair, J. M., Henebry, G. M., Koelliker, J. K., Ramundo, R., and Tate, C. M.: Nitrogen transport from tallgrass prairie watersheds, J. Environ. Qual., 25, 973-981, 1996.

Famiglietti, J. S. and Wood, E. F.: Application of multiscale water and energy balance models on a tallgrass prairie, Water Resour. Res., 30, 3079-3093, 1994.

Famiglietti, J. S. and Wood, E. F.: Effects of spatial variability and scale on areally averaged evapotranspiration, Water Resour. Res., 31, 699-712, 1995.

Famiglietti, J. S., Wood, E. F., Sivapalan, M., and Thongs, D. J.: A catchment scale water balance model for FIFE, J. Geophys. Res., 97, 18997-19007, 1992.

Gutowski Jr., W. J., Vörösmarty, C. J., Person, M., Ötles, Z., Fekete, B., and York, J.: A coupled land-atmosphere simulation program (CLASP): Calibration and validation, J. Geophys. Res., 107, 117, 2002.

Haitjema, H. M., Kelson, V., and de Lange, W.: Selecting Modflow cell sizes for accurate flow fields, Ground Water, 39, 931-938, 2001.

Hansen, C. V.: Estimates of Freshwater Storage and Potential Natural Recharge for Principal Aquifers in Kansas, Water Resources Investigations 87-4230, US Geological Survey, 1991.
Hayashi, M. and Rosenberry, D. O.: Effects of ground water exchange on the hydrology and ecology of surface water, Ground Water, 40, 309-316, 2002.

Hayden, B. P.: Regional climate and the distribution of tallgrass prairie, in: Grassland Dynamics: Long-Term Ecological Research in Tallgrass Prairie, edited by: Knapp, A. K., Briggs, J. M., Hartnett, D. C., and Collins, S. L., Chapt. 2, Oxford University Press, 1998.

Jordan, P. R.: Streamflow transmission losses in western Kansas, J. Hydr. Eng. Div.-ASCE, 103, 905-919, 1977.

Kansas Weather Data Library: available at: http://www.ksre.ksu. edu/wdl/, last access: October 2011.

Lauwo, S. Y.: A modeling investigation of ground and surface water fluxes for Konza Tallgrass Prairie, Master's thesis, Kansas State University, Department of Civil Engineering, 2007.

Macpherson, G. L.: Hydrogeology of thin limestones - the Konza Prairie LTER site, J. Hydrol., 186, 191-228, 1996.

Macpherson, G. L. and Sophocleous, M.: Fast ground-water mixing and basal recharge in an unconfined, alluvial aquifer, Konza LTER Site, Northern Kansas, J. Hydrol., 286, 271-299, 2004.

McDonald, M. G. and Harbaugh, A. W.: A modular threedimensional ground-water flow model, Techniques of WaterResource Investigation 06-A1, USGS, US Government Printing Office, Washington, 1988.

Oviatt, C. G.: Geomorphology of the Konza Prairie, in: Grassland Dynamics: Long-Term Ecological Research in Tallgrass Prairie, edited by: Knapp, A. K., Briggs, J. M., Hartnett, D. C., and Collins, S. L., Chapt. 3, Oxford University Press, 1998.

Paniconi, C. and Wood, E. F.: A detailed model for simulation of catchment scale subsurface hydrologic processes, Water Resour. Res., 29, 1601-1620, 1993.

Porporato, A. and Rodrigues-Iturbe, I.: Ecohydrology - a challenging multidisciplinary research perspective, Hydrolog. Sci. J., Journal des Sciences Hydrologiques, 47, 811-821, 2002.

Ransom, M. D., Rice, C. W., Todd, T. C., and Wehmueller, W. A.: Soils and soil biota, in: Grassland Dynamics: Long-Term Ecological Research in Tallgrass Prairie, edited by: Knapp, A. K., Briggs, J. M., Hartnett, D. C., and Collins, S. L., Chapt. 4, Oxford University Press, 1998.

Sharpley, A. N. and Williams, J. R.: EPIC Erosion/Productivity Impact Calculator, US Department of Agriculture Technical Bulletin No. 1768, 235 pp., 1990.

Steward, D. R. and Ahring, T.: An analytic solution for groundwater uptake by phreatophytes spanning spatial scales from plant to field to regional, J. Eng. Math., 64, 85-103, doi:10.1007/s10665008-9255-x, 2009.

USDA: Hydrologic soil-cover complexes, in: National Engineering Handbook, National Research Conservation Service, Washington, DC, vol. Part 630 Hydrology, Chapt. 9, 9-1-14, 2004.

USDA: Soil Survey Geographic (SSURGO) database, available at: http://soildatamart.nrcs.usda.gov/, last access: October 2011.

Wang, X., Harmel, R. D., Williams, J. R., and Harman, W. L.: Evaluation of EPIC for assessing crop yield, runoff, sediment and nutrient losses from watersheds with poultry litter fertilization, Trans. ASABE, 49, 47-59, 2006.

White, W. B.: Conceptual models for carbonate aquifers, Ground Water, 7, 15-21, 1969. 
Williams, J. R.: The erosion-productivity impact calculator (EPIC) model: a case history, Philos. T. Roy. Soc. B, 329, 421-428, 1990.

Wood, H. K. and Macpherson, G. L.: Sources of Sr and implications for weathering of limestone under tallgrass prairie, northeastern Kansas, Appl. Geochem., 20, 2325-2342, 2005.
Yang, X., Steward, D. R., de Lange, W. J., Lauwo, S. Y., Chubb, R. M., and Bernard, E. A.: Data model for system conceptualization in groundwater studies, Int. J. Geogr. Inf. Sci., 24, 677-694, 2010.

York, J. P., Person, M., Gutowski, W. J., and Winter, T. C.: Putting aquifers into atmospheric simulation models: an example from the Mill Creek watershed, northeaster Kansas, Adv. Water Resour., 25, 221-238, 2002. 